\title{
SEXUALIDADE NA GESTAÇÃO: REVISÃO INTEGRATIVA
}

\author{
Yonara Franco Mussarelli \\ Enfermeira obstétrica, pós-graduanda em Saúde da Mulher - UNICAMP \\ E-mail: francoyonara9@gmail.com
}

INTRODUÇÃO: Na vivência da sexualidade, o ciclo gravídico é considerado complexo com alterações morfofisiológicas e psicológicas podendo causar impacto na vida do casal. OBJETIVO: Analisar na literatura científica, artigos que relatem sobre a sexualidade na gestação. METODOLOGIA: Trata-se de um estudo de revisão integrativa da literatura, a coleta de dados foi realizada através do levantamento bibliográfico, realizado em abril e maio de 2018, nas seguintes bases de dados: Bireme, Pubmed, Cinahl, Scopus e Cochare. De 1175 artigos previamente, 18 foram selecionados. A questão norteadora deste estudo foi "Como ocorre à sexualidade da mulher durante a gestação?" A seleção e analise dos artigos foi feita por duas pesquisadoras de forma independente. RESULTADOS E DISCUSSÕES: Foram incluídos 18 artigos, de diversas localidades. $\mathrm{Na}$ análise dos dados, dos estudos incluídos foram classificados em duas categorias: 1 "conhecer como a mulher lida com a vida sexual durante a gestação" e 2 "como a mulher exerce a sexualidade durante a gravidez". A categoria 1 destacamos que a saúde sexual de cada indivíduo é importante dentro de um relacionamento, precisa ser uma fonte positiva e respeitosa para se ter prazer e manter segurança nas experiências sexuais. Durante a gestação a satisfação sexual não muda em comparação com os padrões anteriores a gestação, mas a forma de como sentir prazer e como a mulher e seu parceiro conseguem sentir prazer mudam com o avanço da gestação. A categoria 2 traz que as mulheres exercem a sexualidade durante a gravidez, relacionando as mudanças corporais e sua satisfação da sexualidade. A mulher expressa sua sexualidade à medida que é valorizada pelo companheiro. O relacionamento e o conhecimento do casal contribuem muito para se manter a sexualidade durante todo o período de gravidez, o casal pode ter vida sexual ativa durante a gravidez, adaptando-se as mudanças físicas da mulher, respeitando seus medos e buscando criatividade com certa cautela. CONCLUSÃO: As limitações a respeito da sexualidade de cada casal devem ser discutidas e conversadas para que mantenham uma vida saudável 
principalmente na gestação período em que a mulher passa por transformações de seu corpo, podendo influenciar sua autoestima.

Palavras-chave: Saúde da mulher. Gravidez. Sexualidade. 